\title{
A Survey Analysis Of Pre-service Chemistry TEACHERS' CRITICAL THINKING SKILlS
}

\author{
Irwanto Irwanto, Eli Rohaeti and A.K. Prodjosantoso
}

This study aimed at analyzing the level of students' critical thinking skills as well as investigating the correlation between students' critical thinking skills and their grade level. A survey involving 220 pre-service chemistry teachers of Yogyakarta State University, Indonesia was conducted. The sample was taken using the convenience sampling technique. The data were collected using a Critical Thinking Rubric (OHRCT) developed by Oliver-Hoyo (2003). The result of this study shows that (i) the average score of students' critical thinking skills was still considered low (13.95 \pm 2.151$)$, (ii) abstract and written presentation appeared as the components that obtained the highest and the lowest score respectively, (iii) significant difference was found between the score of students' critical thinking skills based on grade level in favour of junior students $(p=0.000)$, and (iv) a moderate positive and linear correlation existed between the students' critical thinking skills and grade level $(r=0.442$, $p=0.000)$. The findings indicate that the improvement in students' critical thinking skills has certain influences on the improvement of students' cognition and learning experience after attending courses in chemistry. Based on the result, several recommendations have been proposed to improve university students' critical thinking skills.

KEYWORDS: Critical Thinking Skills, Grade Level, Pre-service Chemistry Teachers

\footnotetext{
Irwanto Irwanto $\Delta$

Yogyakarta State University Indonesia

Email:Irwanto.2016@student.uny.ac.id

Eli Rohaeti

Yogyakarta State University Indonesia

Email:li_rohaeti@uny.ac.id

A.K. Prodjosantoso

Yogyakarta State University Indonesia

Email : prodjosantoso@uny.ac.id
} 


\section{INTRODUCTION}

Critical thinking skill or CTS appears to be the most relevant skill that determines the success of science learning (Espinosa, Monterola, \& Punzalan, 2013). In addition, CTS is also an important skill that one needs in getting prepared for employment (Sada, Mohd, Adnan, \& Yusri, 2016). Lately, CTS has grown its popularity that some experts have proposed various definitions. Ennis (1996) defines critical thinking skill as a reflective-logical thought that focuses on the logic, reflection and the process of decision making. Meanwhile, Dwyer, Hogan, and Stewart (2014) describes critical thinking skill as a metacognitive process consisting of sub skills such as analyzing, evaluating, and inferring. In addition, critical thinking skill also involves a number of logical reasoning activities including analyzing, synthesizing, deducting, reducing, and inferring (Cheng \& Wan, 2017).

At the present time, the objective of higher education is to enhance students' critical thinking skills (Akyüz \& Samsa, 2009; Brahler, Quitadamo \& Johnson, 2002). It is necessary that university students develop their critical thinking skills during their study in the higher education level (Thomas, 2011). CTS supports the development of students' cognition since it positively influences students' academic achievements. Previous studies have shown that there are positive correlation between CTS and students' achievement (Kamaei \& Weisani, 2013; Karagöl \& Bekmezci, 2015), creative thinking (Birgili, 2015; Chang, Li, Chen, \& Chiu, 2015; Ülger, 2016), self-efficacy (Dehghani, Sani, Pakmehr, \& Malekzadeh, 2011; Erdem, 2015; Uzuntiryaki-Kondakci \& CapaAudin, 2013), reading habits (Bulgurcuoglu, 2016), motivation (Semerci, 2010), and logical thinking (Incikabi, Tuna, \& Biber, 2013). In line with the view, Kirmizi, Saygi, and Yurdakal (2015), Memduhoğlu \& Keleş (2016); Tümkaya, Aybek, \& Aldağ (2009) have confirmed the positive correlation between students' CTS and their problem-solving skills. These insights indicate the major contribution of CTS in preparing students as the generation of the 21st century.

A number of studies on CTS have been conducted involving students from chemistry major. Qing, Jing, and Yan (2010) investigated the influence of inquiry-based chemical experiment on pre-service chemistry teachers' CTS. Unfortunately, forty-two students were known to be in the lower level of CTS, particularly in analysing, evaluating, and inferring scales. Another study was done by Temel (2014) which investigated the effect of problem-based learning on critical thinking disposition or CTD of pre-service chemistry teachers. In the study, it is reported that forty-nine pre-service chemistry teachers obtained a relatively low CTD level in both experimental and control groups. The experimental and the control group obtained post-test score of $86.36 \%$ and 
88.88\% (low-scoring group), 13.64\% and 11.12\% (middle-scoring group), respectively, which result shows that no students were included in the high scoring group. Facts shown in previous literature that were reviewed in this study also show that a number of universities suffer from unsatisfactory CTS level.

Furthermore, Zhou et al. (2012) conducted a study that focused on the attempts made to improve middle school students' CTS in China. The analysis of the pre-test and post-test score in the study shows that students' CTS was considered low. Furthermore, Fuad, Zubaidah, Mahanal, and Suarsini(2017) and Hakim, Liliasari, Kadarohman, and Syah (2016) also found similar problem in occurring in Indonesia. In the study, attempts to improve students' CTS were made by applying inquiry-based learning and mini project lab in chemistry. Meanwhile, Zhou, Yan, Zhao, Liu, and Xing (2012) also found that sixty-one pre-service chemistry teachers' CTS level was low in which their subscale evaluating, and inferring scores were lower than their analysing scores. Pros and cons exist in various studies on the identification of the grade level influence on students' CTS. Evidence of the significant difference of CTS based on the grade level has not yet been obtained (Abu-Dabat, 2013; Azar, 2010; Bisdorf-Rhoades, Ricketts, Irani, Lundy, \& Telg, 2005), even though some other studies have confirmed a significant correlation between these two variables (Babamohamdi \& Khalili, 2005; Haw, 2011; Tümkaya et al., 2009; White et al., 2011).

Students' low CTS level might be caused by the implementation of teachercentered teaching in which students act as passive participants and they are given less hands-on activities. Improving students' CTS level requires higher education institutions to improve teachers' CTS level at first (Qing et al., 2010). It is believed that students with high adequate CTS will have better both academic and non-academic achievement in the field of chemistry. CTS can be learned and improved through the implementation of student-active learning such as experimental activities(Kitot, Ahmad, \& Seman, 2010; Qing et al., 2010). In the context of critical thinking activities, Miri, David, \& Uri (2007) emphasizes on the importance of questions asked by students, students' sceptical minds, curiosity, investigation and attempts to find alternatives to solve various daily life issues. CTS is teachable through the use of appropriate curriculum, courses, as well as appropriate teaching methods and techniques (Akkaya, 2012). With the fine integration of those aspects, students are supported to grow as critical-minded generation.

Critical thinking skill is a useful skill that allows students to develop their minds to face the global era (Živkovic, 2016). In the last two decades, the improvement on students' critical thinking skills has been the main concern in 
the teaching of chemistry. This issue has attracted a number of researchers to deeply investigate this matter across education level (e.g., Acharya, 2017; Hakim et al., 2016; Kazuša, 2012; Kogut, 1996; Smith, 2001; Valdez, Lomoljo, Dumrang, \& Didatar, 2015; White et al., 2011). However, only few studies were conducted in Indonesia related to pre-service chemistry teachers' CTS level. This limitation triggers difficulties in analysing students' CTS level. Whereas, pre-service chemistry teachers are expected to be skilful and critical-minded in order to be able to teach students critical thinking skills. In line with the view, Verburgh, François, Elen, and Janssen (2013) also stated that university graduates have to be skilful in making various decisions by precisely analysing any information related to the matters. Hence, it is highly crucial that preservice teachers have high CTSlevel.

Students with high CTS are likely to perform various cognitive skills such as analysing, interpreting, inferring, explaining, and evaluating in dealing with various issues (Giancarlo \& Facione, 2001). More importantly, Thompson (2011) also emphasizes that critical thinking skills are the key to solve problems, conduct various investigations and to make discoveries. This belief makes sense considering the fact that critical thinking helps students to find precise definition and causes of any changes upon certain variable, as well as to understand correlations among certain variables (Duran \& Dökme, 2016). Based on those considerations, the researchers believe that CTS is an important skill to learn in university. Previous studies also support this statement in which it is known that CTS is a necessary skill that helps students understand chemistry and understand the world. Regarding to the explanation, the objectives of this study covered: (i) analysing pre-service chemistry teachers' CTS level, and categorizing the results based on the grade level, and (ii) investigating the correlation between the CTS and the grade level.

\section{RESEARCH METHODOLOGY OF THE STUDY}

\section{RESEARCH DESIGN}

This study was conducted in the form of survey research using a quantitative approach. Survey refers to the data collection method that is focused on obtaining data from certain people, the vital facts of people, their beliefs, opinions, attitudes, motivations, and behaviours (Kerlinger, 1973). In the context of this study, survey was administered to collect data related to CTS from pre-service chemistry teachers based on the grade level.

\section{SAMPLE OF THE STUDY}

This study consists of 220 pre-service chemistry teachers in the first-year 
(35.00\%), second-year (31.36\%), and third-year (33.64\%) who were attending the basic chemistry laboratory, chemical equilibrium laboratory, and chemical instrument laboratory course, respectively (see Table 1). A survey was conducted on the faculty of Mathematics and Natural Sciences of Yogyakarta State University, Indonesia, in the first semester of the academic year 20172018. Convenience sampling technique was used in the survey, as stated by Fraenkel et al. (2012) that this technique can be used to choose samples based on their availability to participate in the study.

\section{Table 1}

\section{Demographic Characteristics of the Sample.}

\begin{tabular}{cccc}
\hline Grade Level & Female & Male & Total \\
\hline Freshmen & 56 & 21 & 77 \\
Sophomore & 43 & 26 & 69 \\
Junior & 51 & 23 & 74 \\
Total & 150 & 70 & 220 \\
\hline
\end{tabular}

\section{DATA COLLECTION INSTRUMENT}

An adaptation of the Critical Thinking Rubric (OHRCT) developed by OliverHoyo (2003) was used to collect the data. The original rubric was translated to Indonesian, and modifications had been made to fit the need of this study before it was rearranged and validated by 13 science lecturers and tried out to 134 randomly chosen pre-service chemistry teachers in Yogyakarta, Indonesia. OHRCT is used to measure students' CTS level based on their written report. OHRCT consisted of six components, namely abstract, sources of information, organization, relevance, content, and presentation of written lab report. Each subscale in the instrument links to students' cognitive skills based on the Bloom's taxonomy. For instance, the subscale "Abstract" takes students' skills in comprehensively synthesizing the result of an experiment. Another example, subscale "Sources of Information" deals with skills used to seek for related information from previous studies. The rubric is available online at http:/ / pubs.acs.org. The reliability coefficient of the instrument is at 0.84 . Each subscale is scored from 1-5 in which greater score shows better fulfilment of the criteria set in the instrument. The scores that can be obtained by the students ranged from 6 to 30 points. 


\section{Data AnAlysis}

Students' CTS level was classified into three categories; low ( $<14$ points), moderate (14-22 points), and high (>22 points). The data of this study were obtained from students' written laboratory report. Descriptive statistics were employed to see the characteristics of the data including the mean, standard of deviation, and data percentage. The data were then analysed using a regression analysis to see causal relationship between the variables. After that, One-way ANOVA was conducted to identify whether a significant difference between the mean scores obtained by more than two independent groups. Pearson's correlation was then employed to calculate the significance of the correlation between CTS and grade level. The categorization of the correlation referred to the Cohen's categorization (1988) including; small ( $r=0.10$ to 0.29$)$, medium ( $r=0.30$ to 0.49$)$, and large effect ( $r=0.50$ to 1.0$)$. In this study, the level of significance was set at 0.05 and the data analysis was done using SPSS statistics 17.0 for windows (SPSS Inc., Chicago, IL, USA).

\section{FINDINGS OF THE STUDY}

This section describes the result of the statistical measurement of students' written laboratory reports. The reports with various grade levels were scored using the OHRCT instrument to map the CTS profile of 220 pre-service chemistry teachers.

\section{a) Analysis of Pre-service Chemistry Teachers' CTS Level}

The level of CTS was analysed by identifying all components of the written laboratory report by the students. The CTS percentage of freshman, sophomore, and junior students are generally presented in Table 2. Overall, the average CTS score was considered low $(M=13.95, S D=2.151)$. All students who participated in this survey were only able to master the CTS of $46.50 \%$. Out of six subscales investigated in this study, the highest score was found in the "Abstract" component (M=2.45, SD=0.642), while the lowest score was obtained in "Written presentation" component (M=2.11, $\mathrm{SD}=0.726$ ) based on a maximum score of 5.00 . 
Table 2

Percentage of Students' CTS.

\begin{tabular}{|c|c|c|c|c|}
\hline No. & CTS Subscales/Cognitive Skills & Mean & $\begin{array}{c}\text { Std. } \\
\text { Deviation }\end{array}$ & $\begin{array}{c}\text { Percentage } \\
(\%)\end{array}$ \\
\hline 1 & Abstract/Synthesis & 2.45 & 0.642 & 49.00 \\
\hline 2 & $\begin{array}{l}\text { Sources of } \\
\text { information/Knowledge and }\end{array}$ & 2.26 & 0.605 & \\
\hline & evaluation & & & 45.20 \\
\hline 3 & $\begin{array}{l}\text { Organization of the } \\
\text { paper/Analysis }\end{array}$ & 2.38 & 0.597 & 47.60 \\
\hline 4 & $\begin{array}{l}\text { Relevance of the } \\
\text { ideas/Knowledge and }\end{array}$ & 2.42 & 0.618 & \\
\hline & application & & & 48.40 \\
\hline 5 & $\begin{array}{l}\text { Content of the } \\
\text { paper/Comprehension }\end{array}$ & 2.34 & 0.521 & 46.80 \\
\hline 6 & $\begin{array}{l}\text { The written } \\
\text { presentation/Evaluation }\end{array}$ & 2.11 & 0.726 & 42.20 \\
\hline & Total & 13.95 & 2.151 & 46.50 \\
\hline
\end{tabular}

b) Differences in Students' CTS Based on the Grade Level

The average CTS score based on the grade level is presented in Table 3. It can be seen in the table that third-year students (junior) have higher CTS scores compared to the ones obtained by freshman and sophomore. The highest score was obtained by the junior group $(M=15.19)$, followed by sophomore $(\mathrm{M}=13.79)$ and freshman $(\mathrm{M}=12.86)$. Generally, junior students obtained the highest scores in all of the subscales.

Table 3

Students' CTS Subscales by Grade Level.

\begin{tabular}{cccccccc}
\hline \multirow{2}{*}{ Grade } & \multicolumn{7}{c}{ Subscales of Critical Thinking Skills } \\
\cline { 2 - 8 } & Abstract & Information & Organization & Relevance & Content & Present ation & Total \\
\hline Freshm en & 2.21 & 2.04 & 2.33 & 2.29 & 2.22 & 1.78 & 12.86 \\
Sophomore & 2.40 & 2.27 & 2.33 & 2.42 & 2.33 & 2.04 & 13.79 \\
Junior & 2.73 & 2.46 & 2.49 & 2.54 & 2.47 & 2.50 & 15.19 \\
Average & 2.44 & 2.26 & 2.38 & 2.42 & 2.34 & 2.11 & 13.95 \\
\hline
\end{tabular}


64 | Irwanto Irwanto, Eli Rohaeti and A. K. Prodjosantoso

Furthermore, to see the existence of any significant difference between CTS scores across levels, Bonferroni post-hoc analysis was administered. In Table 4 there is the significant difference in CTS scores of students across levels. As described in the table, it can be seen that freshmen, sophomores, and juniors have significant influence on the CTS scores $(p<0.05)$ in favour of junior students.

\section{Table 4}

Post-Hoc Analysis (Bonferroni) for Students' CTS by Grade Levels.

\begin{tabular}{cccccc}
\hline & $\begin{array}{c}\text { (I) Grade } \\
\text { Level }\end{array}$ & $\begin{array}{c}\text { (J) Grade } \\
\text { Level }\end{array}$ & $\begin{array}{c}\text { Mean } \\
\text { Difference (I -J) }\end{array}$ & Std. Error & Sig. \\
\hline \multirow{4}{*}{ Freshmen } & Sophomore & $-0.915^{*}$ & 0.321 & 0.014 \\
& & Junior & $-2.293^{*}$ & 0.315 & 0.000 \\
Critical & & Freshmen & $0.915^{*}$ & 0.321 & 0.014 \\
Thinking & \multirow{2}{*}{ Sophomore } & Junior & $-1.378^{*}$ & 0.324 & 0.000 \\
Skills & & Freshmen & $2.293^{*}$ & 0.315 & 0.000 \\
& \multirow{2}{*}{ Junior } & Sophomore & $1.378^{*}$ & 0.324 & 0.000 \\
\hline
\end{tabular}

*. The mean difference is significant at the 0.05 level.

Deeper exploration of students' CTS scores in each category, i.e. low, moderate and high is presented in the form of percentage (see Table 5). Freshman students dominate the lowest CTS level as much as $23.6 \%$, while junior students have the lowest one $(1.8 \%)$ since they obtained satisfactory scores more than 22 points which could not be obtained by any freshmen. Therefore, it can be concluded that the majority of the students $(96.8 \%)$ scored less than 22 points.

Table 5

Percentage of Students' CTS Level.

\begin{tabular}{ccccc}
\hline \multirow{2}{*}{ Grade Level } & \multicolumn{4}{c}{ Percentage of CTS Level(\%) } \\
\cline { 2 - 5 } & $\begin{array}{c}\text { Low } \\
<\mathbf{1 4} \text { pts. }\end{array}$ & $\begin{array}{c}\text { Moderate } \\
\mathbf{1 4 - 2 2} \text { pts. }\end{array}$ & $\begin{array}{c}\text { High } \\
>\mathbf{2 2} \text { pts. }\end{array}$ & Total \\
\hline Freshmen & 23.6 & 11.4 & 0 & 35.0 \\
Sophomore & 15.9 & 14.1 & 1.4 & 31.4 \\
Junior & 1.8 & 30.0 & 1.8 & 33.6 \\
Total & 41.3 & 55.5 & 3.2 & 100.0 \\
\hline
\end{tabular}

c) The Correlation between CTS and Grade Level

The result of data analysis using the Pearson's correlation (see Table 6), a positive and significant correlation exists between CTS and the grade level 
$(\mathrm{r}=0.442, \mathrm{p}=0.000)$. According to the criteria set by Cohen (1988), the coefficient obtained in the analysis is included in the medium category. Based on the result of the measurement, it can be concluded that grade level improvement positively influences students' CTS. This finding implies that junior students tend to obtain higher CTS scores than freshman and sophomores.

Table 6

Pearson Correlation for CTS-Grade Level.

\begin{tabular}{lcc}
\hline & Critical Thinking Skills & Grade Level \\
\hline Critical Thinking Skills & 1.000 & 0.442 \\
Grade Level & 0.442 & 1.000 \\
\hline
\end{tabular}

Linear regression was administered to see the direction of the correlation. Based on the result of the regression analysis, it is known that a linear correlation exists between CTS and grade level (see Table 7). The statistical data shows that grade level explains $19.5 \%$ of the total variance in CTS score. This result indicates a moderate positive and linear correlation between students' CTS and grade level. In another word, grade level can be used to predict students' CTSlevel.

Table 7

Linear Regression Analysis for Critical Thinking Skills.

\begin{tabular}{cccccc}
$\mathbf{R}$ & $\mathbf{R}^{2}$ & $\mathbf{F}$ & $\mathbf{B}$ & $\boldsymbol{t}$ & Sig. \\
\hline 0.442 & 0.195 & 52.909 & 11.680 & 34.473 & 0.000 \\
\hline
\end{tabular}

\section{DISCUSSION}

Improvement on students' CTS is one of main goals of chemistry teaching curriculum in Indonesia. In this study, researchers have successfully analysed the CTS level of pre-service chemistry teachers and investigated the correlation between CTS and grade level. The result of this current study generally indicates that students' CTS is still considered low. Most students are included in the low up to moderate CTS level. Similar result was also found by Fuad et al. (2017); Hadi, Susantini, and Agustini(2018); Hakim et al. (2016); Hapsari (2016); Puspita, Kaniawati, and Suwarma (2017); Qing et al.(2010); Temel (2014); Zhou, Ma, et al.(2012); and Zhou, Yan, et al. (2012)in which they explained that the poor result might be caused by the failure of the teaching and learning activities in facilitating students to think critically. In the study, various attempts to improve the condition were made such as applying various methods, strategies and student-active learning activities including 
inquiry, experiment, problem-based learning, and mini project laboratory. Students' higher CTS improves the probability for the students to obtain better academic achievements (Kazuša, 2012).

It was found in this study that the component of written presentation report is the trait with the lowest score, followed by sources of information, content, organization of the paper, and abstract. Written presentation is highly linked with domain evaluation, while sources of information is related to the knowledge and evaluation. Whereas, the content of the paper is linked with the comprehension in Bloom's taxonomy (Oliver-Hoyo, 2003). Students' poor writing ability has also been confirmed in other studies. Afrin (2016), for example, found out that students' writing ability in Bangladesh was also weak. There are several factors that cause low writing quality such as the lack of practice in article writing, inadequate literature review, low text coherence and organization, and the lack of formal training in scientific writing (Chokwe, 2013; Marušić, Mišak, \& Marušić, 2002; Olwell \& Delph, 2004). As a matter of fact, scientific writing ability is correlated with CTS. In another word, better scientific writing ability improves students' critical thinking. Thus, attempts to improve chemistry students' CTS can be done by improving students' ability in writing laboratory report (e.g., Gupta, Burke, Mehta, \& Greenbowe, 2015; Kovac \& Sherwood, 1999; Oliver-Hoyo, 2003; Stephenson \& Sadler-McKnight, 2016).

A statistically significant difference was found between students' CTS scores and the grade level. The highest CTS score is obtained by junior students, followed by sophomores and freshman. In the last few decades, education practitioners and researchers have conducted some studies that investigated different grade level in CTS. Similar result was also found by Haw (2011); Kermansaravi, Navidian, and Kaykhaei (2013); Ralston and Bays (2013); Rollins (1990); Tümkaya et al.(2009); and White et al. (2011) whose study reported that students in the high grade level tend to have better CTS score. In addition, Onwuegbuzie (2001) compared graduate and postgraduate students' CTS. In the study, it was found that postgraduate students obtained a significantly better CTS result than graduate students. This result indicates that the level of CTS is influenced by students' cognitive development. Furthermore, the development of students' cognition influences students' ability to think critically and logically.

Even though junior students obtained higher CTS scores compared to the ones obtained by sophomores and freshman, yet those three group have not yet obtained a satisfactory result. A number of students were included in the lowest level of CTS. Moreover, there was no freshman student who managed to 
reach the high level of CTS. In relation to the finding, Rivas (2017) stated that students' poor CTS is indicated by students' limited conceptual knowledge and the lack of activities which drive students to think critically. Moreover, previous studies have also linked with environmental and learning method issues (e.g., Duron, Limbach, \& Waugh, 2006; Salsali, Tajvidi, \& Ghiyasvandian, 2013; Wiesner et al., $\square 2017$ ). Regarding to the fact, it is suggested that teachers shift their teaching paradigm to constructivism and improve students' CTS by implementing student-centered teaching and learning activities.

In case of association, a moderate positive and linear correlation has been found between students' CTS and grade level. This finding implies that students in the lower grade would likely to obtain lower CTS scores, while students in the higher-grade level will obtain higher CTS scores. Several studies on this phenomena have been done such as the one conducted by Cano and Martinez (1991) who analysed secondary school students' critical thinking ability, which study found that twelve graders consistently obtained higher scores than those from other grades (grade 9-11). In a separated study, Tümkaya et al. (2009) investigated university students' critical thinking disposition from various majors. The study confirmed that students' critical thinking improved as the students continued their study to higher degree. The study also suggests that higher education curriculum include education programs that focus on enhancing students' critical thinking skills.

To have high CTS is the essential goal of universities in preparing students to become professionals. The fact that at this present time university students show relatively low CTS urges universities to improve this condition by implementing certain programs. Qing et al. (2010) suggest that universities apply experiment-based teaching method in the teaching of chemistry courses in order to engage students into activities that require them to think critically, besides there has to be a fine integration between the teaching of theories and practices. In addition, Muhlisin, Susilo, Amin, and Rohman (2016) recommends practitioners to use mind mapping strategy to support the teaching and learning. Wartono, Hudha, and Batlolona (2018) emphasizes on the implementation of an inquiry-discovery method, while Soltis, Verlinden, Kruger, Carroll, \& Trumbo (2015) proposes a process-oriented guided inquiry learning strategy to improve students' CTS. The students need to have high CTS to be able to analyse various supporting facts, find logical solutions, put the knowledge into real life practices, and to be actively involved as a part of the global society. All of those necessities can be facilitated by implementing a constructivist learning method. 


\section{CONCLUSIONS AND SUGGESTIONS}

This study shows that generally, the average score of students' CTS is considered low and written presentation has been the component that appears as the trait with the lowest score. On top of that, there was no freshman student who managed to achieve the high CTS level. Statistically, a significant difference was found in students' CTS scores when the scores were sorted by the grade level. The result of the correlation analysis indicates a moderate positive and linear correlation between CTS and grade level. It is highlighted that junior students obtained higher CTS scores in all of the subscales used in this study compared to freshman students and sophomores. The high CTS scores found in the upper grades might be related to students' better cognitive development and richer experience after attending several courses in chemistry. However, it is necessary to improve this outcome. It is also suggested that students are given independence in conducting their preferred experiments through discovery learning instead of merely sticking on the guidebook. More importantly, students should be trained to think critically by providing workshops in chemistry laboratory report writing and other scientific writing training. Furthermore, teachers should always apply student-centered learning that supports students to experience better learning process and better learning achievement.

\section{REFERENCES}

Abu-Dabat, Z. I. (2013). The achievement and development of critical thinking skills in the arabic language of adolescent pupils with reference to the primary stage throughout Jordan. International Jounal of Humanities and Social Science, 3(5), 155-162.

Acharya, K. P. (2017). Exploring critical thinking for secondary level students in chemistry: From insight to practice. Journal of Advanced College of Engineering and Management, 3, 31-39.

Afrin, S. (2016). Writing problems of non-english major undergraduate students in Bangladesh: An observation. Open Journal of Social Sciences, $4,104-115$.

Akkaya, N. (2012). The relationship between teachers candidates' critical thinking skills and their use of reading strategies. Procedia - Social and Behavioral Sciences, 47,797-801.

Akyüz, H. I., \& Samsa, S. (2009). The effects of blended learning environment on the critical thinking skills of students. Procedia Social and Behavioral Sciences, 1, 1744-1748.

Azar, A. (2010). The effect of critical thinking dispositions on students achievement in selection and placement exam for university in Turkey. Journal of Turkish Science Education, 7(1), 61-73. 
Babamohamdi, H., \& Khalili, H. (2005). Comparison of critical thinking skills in students of nursing in continuous and interrupted BS sections of Semnan University of Medical Sciences. Journal of Medical Education, $6(2), 169-174$.

Birgili, B. (2015). Creative and critical thinking skills in problem-based learning environments. Journal of Gifted Education and Creativity, 2(2), 71-80.

Bisdorf-Rhoades, E., Ricketts, J., Irani, T., Lundy, L., \& Telg, R. (2005). Critical thinking dispositions of agricultural communications students. Journal of Applied Communications, 89 (1), 25-34.

Brahler, C. J., Quitadamo, I. J., \& Johnson, E. C. (2002). Student critical thinking is enhanced by developing exercise prescriptions using online learning modules. Advances in Physiology Education,26(3), 210-221.

Bulgurcuoglu, A. N. (2016). Relationship between critical thinking levels and attitudes towards reading habits among pre-service physical education teachers. Educational Research and Reviews, 11(8), 708-712.

Cano, J., \& Martinez, C. (1991). The relationship between cognitive performance and critical thinking abilities among selected agricultural education students. Journal of Agricultural Education, 31(2), 24-29.

Chang, Y., Li, B.-D., Chen, H.-C., \& Chiu, F.-C. (2015). Investigating the synergy of critical thinking and creative thinking in the course of integrated activity in Taiwan. Educational Psychology, 35(3), 341-360.

Cheng, M. H. M., \& Wan, Z. H. (2017). Exploring the effects of classroom learning environment on critical thinking skills and disposition: A study of Hong Kong 12th graders in liberal studies. Thinking Skills and Creativity, 24, 152-163.

Chokwe, J. M. (2013). Factors impacting academic writing skills of english second language students. Mediterranean Journal of Social Sciences, 4(14), 377-383.

Cohen, J. (1988). Statistical power analysis for the behavioral sciences (2nd ed.). Hillsdale, NJ: Lawrence Earlbaum Associates.

Dehghani, M., Sani, H. J., Pakmehr, H., \& Malekzadeh, A. (2011). Relationship between students' critical thinking and self-efficacy beliefs in Ferdowsi University of Mashhad, Iran. Procedia - Social and Behavioral Sciences, 15, 2952-2955.

Duran, M., \& Dökme, I. (2016). The effect of the inquiry-based learning approach on student's critical-thinking skills. Eurasia Journal of Mathematics, Science and Technology Education, 12(12), 2887-2908.

Duron, R., Limbach, B., \& Waugh, W. (2006). Critical thinking framework for any discipline. International Journal of Teaching and Learning in Higher Education, 17(2), 160-166.

Dwyer, C. P., Hogan, M. J., \& Stewart, I. (2014). An integrated critical thinking framework for the 21st century. Thinking Skills and Creativity, 12, 43-52.

Ennis, R. H. (1996). Critical thinking dispositions: Their nature and 
assessability. Informal Logic, 18(2\&3), 165-182.

Erdem, E. (2015). The relationship between self-efficacy and attitudes of chemistry teacher candidates. Problems of Education in the 21st Century,63, 62-70.

Espinosa, A. A., Monterola, S. L. C., \& Punzalan, A. E. (2013). Career-oriented performance tasks in chemistry: Effects on students' critical thinking skills. Education Research International, 2013(Article ID 834584), 1-10.

Fuad, N. M., Zubaidah, S., Mahanal, S., \& Suarsini, E. (2017). Improving junior high schools' critical thinking skills based on test three different models of learning. International Journal of Instruction, 10(1), 101-116.

Fraenkel, J. R., Wallen, N. E., \& Hyun, H. H. (2012). How to design and evaluate research in education (8thed.). New York, NY: McGraw-Hill.

Giancarlo, C. A., \& Facione, P. A. (2001). A look across four years at the disposition toward critical thinking among undergraduate students. The Journal of General Education, 50(1), 29-55.

Gupta, T., Burke, K. A., Mehta, A., \& Greenbowe, T. J. (2015). Impact of guided-inquiry-based instruction with a writing and reflection emphasis on chemistry students' critical thinking abilities. Journal of Chemical Education, 92(1), 32-38.

Hadi, S. A., Susantini, E., \& Agustini, R. (2018). Training of students' critical thinking skills through the implementation of a modified free inquiry model. Journal of Physics: Conference Series, 947, 12063. https:/ / doi.org/10.1088/1742-6596/947/1/012063.

Hakim, A., Liliasari, Kadarohman, A., \& Syah, Y. M. (2016). Improvement of student critical thinking skills with the natural product mini project laboratory learning. Indonesian Journal of Chemistry, 16(3), 322-328.

Hapsari, S. (2016). A descriptive study of the critical thinking skills of social science at junior high school. Journal of Education and Learning, 10(3), 228-234.

Haw, J. (2011). Improving psychological critical thinking in Australian university students. Australian Journal of Psychology, 63(3), 150-153.

Incikabi, L., Tuna, A., \& Biber, A. C. (2013). An analysis of mathematics teacher candidates' critical thinking dispositions and their logical thinking skills. Journal of International Education Research, 9(3), 257-267.

Kamaei, A., \& Weisani, M. (2013). The relationship between achievement motivation, critical thinking and creative thinking with academic performance. Indian Journal of Fundamental and Applied Life Sciences, 3(4), 121-127.

Karagöl, İ., \& Bekmezci, S. (2015). Investigating academic achievements and critical thinking dispositions of teacher candidates. Journal of Education and Training Studies, 3(4), 86-92.

Kazuša, I. (2012). Usage of critical thinking strategies in the chemistry course for a future doctor. Problems of Education in the 21st Century,41,18-27.

Kerlinger, F. N. (1973). Foundations of behavioural research. New York: Holt, 
Rinehart, \& Winston.

Kermansaravi, F., Navidian, A., \& Kaykhaei, A. (2013). Critical thinking dispositions among junior, senior and graduate nursing students in Iran. Procedia - Social and Behavioral Sciences, 83, 574-579.

Kirmizi, F. S., Saygi, C., \& Yurdakal, I. H. (2015). Determine the relationship between the disposition of critical thinking and the perception about problem solving skills. Procedia - Social and Behavioral Sciences, 191, 657-661.

Kitot, A. K. A., Ahmad, A. R., \& Seman, A. A. (2010). The effectiveness of inquiry teaching in enhancing students' critical thinking. Procedia Social and Behavioral Sciences, 7(C), 264-273.

Kogut, L. S. (1996). Critical thinking in general chemistry. Journal of Chemical Education, 73(3), 218-221.

Kovac, J., \& Sherwood, D. W. (1999). Writing in chemistry: An effective learning tool. Journal of Chemical Education, 76(10), 1399-1403.

Marušić, A., Mišak, A., \& Marušić, M. (2002). Clarity of scientific presentation: Prerequisite for the communication between scientist and the public. Medijska iItraživanja, 8(2), 5-18.

Memduhoğlu, H. B., \& Keleş, E. (2016). Evaluation of the relation between critical-thinking tendency and problem-solving skills of pre-service teachers. Journal of Educational Sciences Research, 6(2), 75-94.

Miri, B., David, B.-C., \& Uri, Z. (2007). Purposely teaching for the promotion of higher-order thinking skills: A case of critical thinking. Research in Science Education, 37, 353-369.

Muhlisin, A., Susilo, H., Amin, M., \&Rohman, F. (2016). Improving critical thinking skills of college students through RMS model for learning basic concepts in science. Asia-Pacific Forum on Science Learning and Teaching, 17(1), 1-24.

Oliver-Hoyo, M. T. (2003). Designing a written assignment to promote the use of critical thinking skills in an introductory chemistry course. Journal of Chemical Education, 80(8), 899-903.

Olwell, R., \& Delph, R. (2004). Implementing assessment and improving undergraduate writing: One department's experience. The History Teacher, 38(1), 21-34.

Onwuegbuzie, A. J. (2001). Critical thinking skills: A comparison of doctoraland master's-level students. College Student Journal, 35(3), 477-481.

Puspita, I., Kaniawati, I., \& Suwarma, I. R. (2017). Analysis of critical thinking skills on the topic of static fluid. Journal of Physics: Conference Series, 895, 12100. https://doi.org/10.1088/1742-6596/895/1/012100.

Qing, Z., Jing, G., \& Yan, W. (2010). Promoting preservice teachers' critical thinking skills by inquiry-based chemical experiment. Procedia Social and Behavioral Sciences, 2, 4597-4603.

Ralston, P. A., \& Bays, C. L. (2013). Enhancing critical thinking across the undergraduate experience: An exemplar from engineering. American 
Journal of Engineering Education, 4(2), 119-126.

Rivas, P. G. (2017). Strategies for teaching and dissemination of artistic heritage by promoting critical and creative thinking among future primary education teachers. Procedia-Social and Behavioral Sciences, 237, 717-722.

Sada, A. M., Mohd, Z. A., Adnan, A., \& Yusri, K. (2016). Prospects of problembased learning in building critical thinking skills among technical college students in Nigeria. Mediterranean Journal of Social Sciences, 7(3), 356-365.

Salsali, M., Tajvidi, M., \& Ghiyasvandian, S. (2013). Critical thinking dispositions of nursing students in Asian and non-Asian countries: A literature review. Global Journal of Health Science, 5(6), 172-178.

Semerci, Ç. (2010). The relationships between self leadership and critical thinking. African Journal of Business Management, 5(15), 6180-6185.

Smith, A. (2001). Strategies to improve critical thinking skills in high school students. Perspectives in Learning, 2(1), 8-11.

Soltis, R., Verlinden, N., Kruger, N., Carroll, A., \& Trumbo, T. (2015). Processoriented guided inquiry learning strategy enhances students' higher level thinking skills in a pharmaceutical sciences course. American Journal of Pharmaceutical Education, 79(1), 1-8.

Stephenson, N. S., \& Sadler-McKnight, N. P. (2016). Developing critical thinking skills using the science writing heuristic in the chemistry laboratory. Chem. Educ. Res. Pract., 17(1), 72-79.

Temel, S. (2014). The effects of problem-based learning on pre-service teachers' critical thinking dispositions and perceptions of problemsolving ability. South African Journal of Education, 34(1), 1-20.

Thomas, T. (2011). Developing first year students' critical thinking skills. Asian Social Science, 7(4), 26-33.

Thompson, C. (2011). Critical thinking across the curriculum: Process over output. International Journal of Humanities and Social Science, 1(9), 1-7.

Tümkaya, S., Aybek, B., \& Aldağ, H. (2009). An investigation of university students' critical thinking disposition and perceived problem solving skills. Eurasian Journal of Educational Research, Summer(36), 57-58.

Ülger, K. (2016). The relationship between creative thinking and critical thinking skills of students. Hacettepe University Journal of Education, 31(4), 695-710.

Uzuntiryaki-Kondakci, E., \&Capa-Audin, Y. (2013). Predicting critical thinking skills of university students through metacognitive selfregulation skills and chemistry self-efficacy. Educational Sciences: Theory $\mathcal{E}$ Practice, 13(1), 666-670.

Valdez, A. V, Lomoljo, A., Dumrang, S. P., \& Didatar, M. M. (2015). Developing critical thinking through activity-based and cooperative learning approach in teaching high school chemistry. International Journal of Social Science and Humanity, 5(1), 139-141. 
Verburgh, A., François, S., Elen, J., \& Janssen, R. (2013). The assessment of critical thinking critically assessed in higher education: A validation study of the CCTT and the HCTA. Education Research International, 1-13.

Wartono, W., Hudha, M. N., \& Batlolona, J. R. (2018). How are the physics critical thinking skills of the students taught by using inquiry-discovery through empirical and theorethical overview? Eurasia Journal of Mathematics, Science and Technology Education, 14(2), 691-697.

White, B., Stains, M., Escriu-Sune, M., Medaglia, E., Rostamnjad, L., Chinn, C., \& Sevian, H. (2011). A novel instrument for assessing students' critical thinking abilities. Journal of College Science Teaching, 40(5), 102-107.

Wiesner, S. M., Walker J. D., \& Creeger, C. R. (2017). Improving critical thinking using a web-based tutorial environment. Journal of Allied Health, 46(2), 111-116.

Zhou, Q., Ma, L., Huang, N., Liang, Q., Yue, H., \& Peng, T. (2012). Integrating webquest into chemistry classroom teaching to promote students' critical thinking. Creative Education, 3(3), 369-374.

Zhou, Q., Yan, C., Zhao, S., Liu, L., \& Xing, L. (2012). A preliminary investigation into critical thinking of in-service and pre-service middle school chemistry teachers in Shaanxi province of China. Asia-Pacific Forum on Science Learning and Teaching, 13(2), 1-13.

Živkovic, S. (2016). A model of critical thinking as an important attribute for success in the 21st century. Procedia - Social and Behavioral Sciences, 232, 102-108. 